Journal of Applied Business, Taxation and Economics Research (JABTER)

Vol. 1, No. 3, February 2022 (Page: 257-267)

DOI: $10.54408 /$ jabter.v1i3.49

E-ISSN 2808-263X

\title{
The Effect of Financial Reporting Accountability on the Participation Level of UNEJ Student Support to Non-Governmental Organizations
}

\author{
Galang Nusantara Achmad ${ }^{1 *}$, Zakwan Hammam², Regita Desta Sekar Sari ${ }^{3}$ \\ $1^{*}, 2,3$ Jember University
}

Corresponding Author: galanngna@gmail.com ${ }^{1 *}$ )

Keywords : Accountability, Participation, Financial Reporting, Non-Governmental Organizations

\begin{abstract}
:
This study aims to tested the effect of Financial Reporting Accountability on Unej Student Support Participation to Non-Governmental Organizations. This study uses a descriptive quantitative approach. The population in this study were active students at the University of Jember. The results showed that the value of the significance of $0.000<0.005$, it can be concluded that the Financial Reporting Accountability variable $(X)$ has a positive effect on the Participation Rate of UNEJ Student Support to NonGovernmental Organizations $(Y)$. While the $K D$ value is 0.417 . From this it was found that the importance of financial reporting accountability is one of the responsibilities of non-governmental organizations information to the public, and this can also contribute to obtaining the support of public sympathizers, including students.
\end{abstract}




\section{Introduction}

In general, non-profit organizations with business organizations are different. Not-forprofit organizations focus on not making a profit from every business they do. Non-profit organizations are managed by the public or private sector and the capital obtained is obtained by donors. Examples of non-profit organizations such as churches, mosques, political parties and zakat institutions. Although not-for-profit organizations do not focus on profit, non-profit organizations still make financial reports that are used as a form of accountability for creditors, organizational members, donors and other parties involved.

One of the principles of good government is accountability, where accountability emphasizes the delivery of budget realization to the public (Fauzi, 2018). Accountability is a form of obligation for the provider of the implementation of public activities as an accountability for the steps, decisions, and results that have been achieved (Lukito, 2014). Non-profit organizations must be able to convey financial information in a timely, open and of course prepared according to accounting standards. It can be concluded, with accountability, the public can know all the activities of an organization.

Scott quoted by Mulyana (2006) explains that organizational sustainability is determined by the ability to open, balanced and equal information for all parties involved. Financial reports here must be able to assist users in making decisions, therefore accountability will foster a sense of commitment for workers to the organization. With commitment, the organization can develop in the same direction and in line with efforts to realize organizational programs, in other words commitment can affect individual motivation to determine something. Information disclosure is a global phenomenon that has been recognized in almost all countries. Including in Indonesia. Disclosure of public information is a strategic issue in an effort to achieve good governance, which is the common goal of the Indonesian people.

Furthermore, the existence of Non-Governmental Organizations that are increasingly popping up shows the image that non-profit organizations are present in the midst of society in providing the best service. Therefore, of course, the existence of Non-Governmental Organizations must be able to place themselves in the community as an effort to get support from sympathizers for the sustainability of the organization. Students are no exception, the existence of Non-Governmental Organizations is now also a medium in voicing issues that are in line with students. So from this, researchers are interested in examining the effect of financial reporting accountability on the participation level of student support for Non-Governmental Organizations. Meanwhile, the researcher places a case study to examine the Indonesian Corruption Watch Non-Governmental Organization.

\section{Research Method}

This research uses a descriptive quantitative approach. The use of quantitative descriptive research methods aims to explain a condition by using numbers that describe the characteristics 
of the variables studied in a factual, systematic, and accurate manner. Meanwhile, according to Sudjana (1997) the purpose of descriptive research is to be able to read and explain the meanings known in the study.

This study uses primary and secondary data sources. Primary data comes from questionnaires distributed to respondents, while secondary data comes from various journal articles to support research results. The data collection technique is by distributing online questionnaires to active students at the University of Jember with random sampling technique. The number of samples in this study refers to the requirements of quantitative research, namely at least 30 samples.

As for the data analysis technique, this study uses a statistical test tool in the form of a simple linear regression test with various prerequisite tests that must be met including validity tests, reliability tests, normality tests, and linearity tests. Meanwhile, in processing the questionnaire data, researchers used SPSS software to provide accurate research results.

\section{Result and Discussion}

There are several classical assumption tests that must be carried out before the data can be tested by simple linear regression analysis. The classical assumption tests that must be met include validity tests, reliability tests, normality tests, and linearity tests. Furthermore, if the data has met the four types of classical assumption tests, then the data is feasible for simple regression analysis.

Validity Test

Test Validity test is used to test whether the data attributes in a study are valid or not (Sugiyono, 2008). In other words, attribute data can be used to measure something you want to measure. As for the number of respondents used in this study as many as $(n)=32$, it can be seen that the value of $r$ table at the $5 \%$ error significance level is 0.349 . From the results of the validity test with the help software, it was found that the two variable items of Financial Reporting Accountability $(X)$ and the Participation Level of UNEJ Student Support to Non-Governmental Organizations $(Y)$ showed the value of $r$ arithmetic $>r$ table. Thus, it can be concluded that all the attributes of the questionnaire data used in this study are valid.

\section{Reliability Test Reliability Test}

Test is intended to find out how far the results of the measurements carried out show consistency if the measurement test is repeated repeatedly on the same object (Notoatmodjo, 2005). The research data is said to be reliable if the value of Cronbach's alpha is > 0.6 (Ghozali, 2011). 
Table 1. Reliability Test of Financial Reporting Accountability Variables (X)

Reliability Statistics

\begin{tabular}{|c|c|}
\hline Cronbach's & $\mathrm{N}$ \\
\hline Alpha & Items \\
\hline .926 & 10 \\
\hline
\end{tabular}

Source: SPPS 2021 data, processed

Based on the results of reliability testing with software on the instrument variable Financial Reporting Accountability $(X)$ which consists of 10 items The question shows the results of Cronbach's alpha of $0.926>0.6$.

Table 2. Results of Variable Reliability of Participation Rate of UNEJ Student Support to Non-

Governmental Organizations ( $Y$ )

Reliability Statistics

\begin{tabular}{|c|c|}
\hline Cronbach's & $\mathrm{N}$ \\
\hline Alpha & Items \\
\hline .764 & 10 \\
\hline
\end{tabular}

Source: SPPS 2021 data, processed

While in the reliability test the instrument Participation Rate of UNEJ Student Support to Non-Governmental Organization $(Y)$ which consists of 10 question items showing the results of Cronbach's alpha of $0.764>0.6$. So that it can be said that the two variables, namely Financial Reporting Accountability (X) and the Participation Level of UNEJ Student Support to NonGovernmental Organizations $(Y)$ with each attribute of 10 question items being reliable.

Normality Test

Test The normality test is used to measure whether the regression equation model, namely the independent variable and the dependent variable has a normal distribution or not (Ghozali, 2011). In the normality test, a data can be said to have a normal distribution if the significance value is $>0.05$ (Priyatno, 2009). As for the normality test for the data attributes of the question items consisting of the Financial Reporting Accountability variable (X) and the Participation Rate variable for UNEJ Student Support to Non-Governmental Organizations (Y) using the Liliefors by looking at the values in the Kolmogorov-Smirnov table.

Table 3. Normality Test Results

One-Sample Kolmogorov-Smirnov Test

Unstandardiz

ed Residual

\begin{tabular}{lc}
\hline $\mathrm{N}$ & 32 \\
\hline
\end{tabular}




\begin{tabular}{|c|c|c|}
\hline \multirow[t]{3}{*}{ Normal Parameters ${ }^{a, b}$} & Mean & .0000000 \\
\hline & Std. & 3.25525070 \\
\hline & \multicolumn{2}{|c|}{ Deviation } \\
\hline Extreme & Absolute & .124 \\
\hline \multirow[t]{2}{*}{ Differences } & Positive & .060 \\
\hline & Negative & -124 \\
\hline \multicolumn{2}{|l|}{ Test Statistic } & .124 \\
\hline \multicolumn{2}{|l|}{ Asymp. Sig. (2-tailed) } & $.200^{c, d}$ \\
\hline \multicolumn{3}{|c|}{ a. Test distribution is Normal. } \\
\hline \multicolumn{3}{|l|}{ b. Calculated from data. } \\
\hline \multicolumn{3}{|c|}{ c. Lilliefors Significance Correction. } \\
\hline \multicolumn{3}{|c|}{ d. This is a lower bound of the true significance. } \\
\hline \multicolumn{3}{|c|}{ Source: SPPS 2021 data, processed. } \\
\hline
\end{tabular}

Based on the results of the normality test with software the significance value in the Kolmogorov-Smirnov table is $0.200>0.05$, with Thus it can be said that the data used in this study, namely the data attributes of the question items for the Financial Reporting Accountability variable (X) and the Participation Rate of UNEJ Student Support to Non-Governmental Organizations $(\mathrm{Y})$ contribute normally and can be used for simple regression analysis calculations.

\section{Linearity Test}

Test The linearity test aims to test whether the regression model equation between the independent variable and the dependent variable has a match or not (Ghozali, 2011). Two variables can be said to have a significant linear relationship if the significance value for deviation from linearity is $>0.05$ (Nabila \& Isroah, 2019).

Table 4. Linearity Test

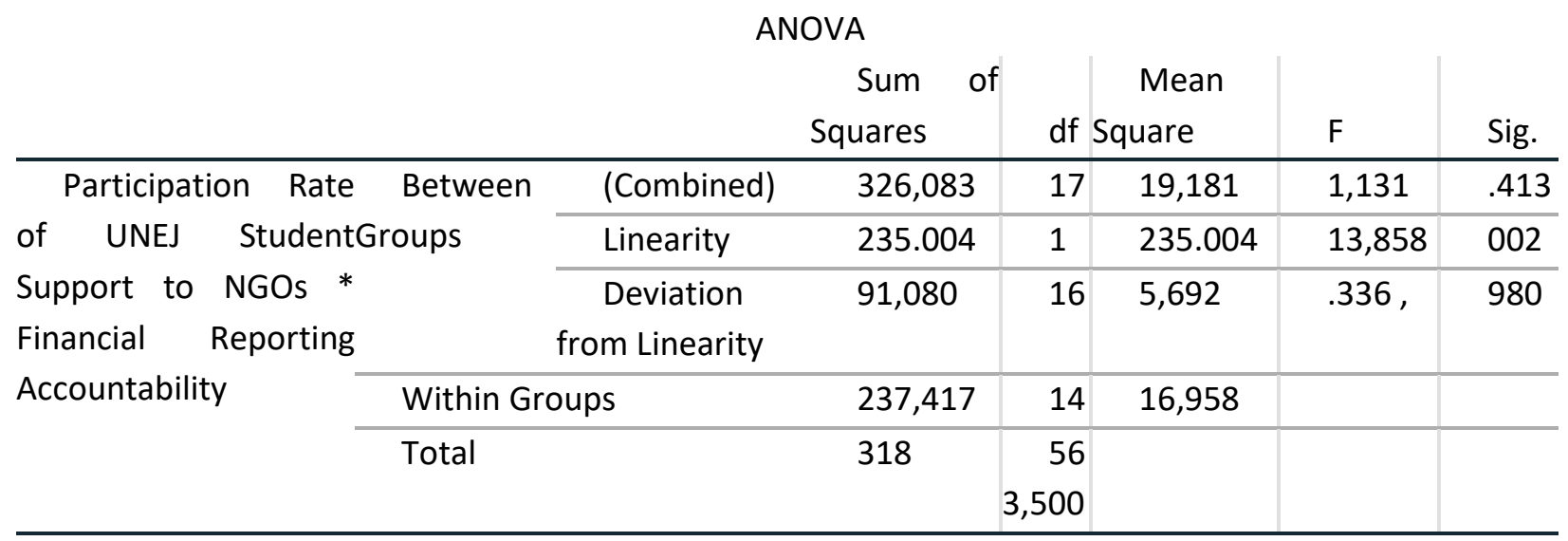

Source: SPPS 2021, processed 
From the results of the linearity test using software, it is known that the deviation from linearity value is $0.980>0.05$, so it can be concluded that there is a significant linear relationship between the Financial Reporting Accountability $(X)$ variable and the Participation Rate variable for UNEJ Student Support to InstitutionsGovernmental Organization (Y).

\section{Simple Linear Regression Test}

Analysis has several functions, one of which is intended to predict the dependent variable (Y) (Smadi and Abu-Afouna, 2012). In addition, in this study, simple linear regression analysis was also used to test the effect between two variables. The basis for making decisions on the regression test is done by comparing the significance value with the probability value. If the significance value $<0.05$, it means that there is an influence between the independent variable $(\mathrm{X})$ and the dependent variable $(\mathrm{Y})$.

Table 5. Simple Regression Test Results ANOVA $^{a}$

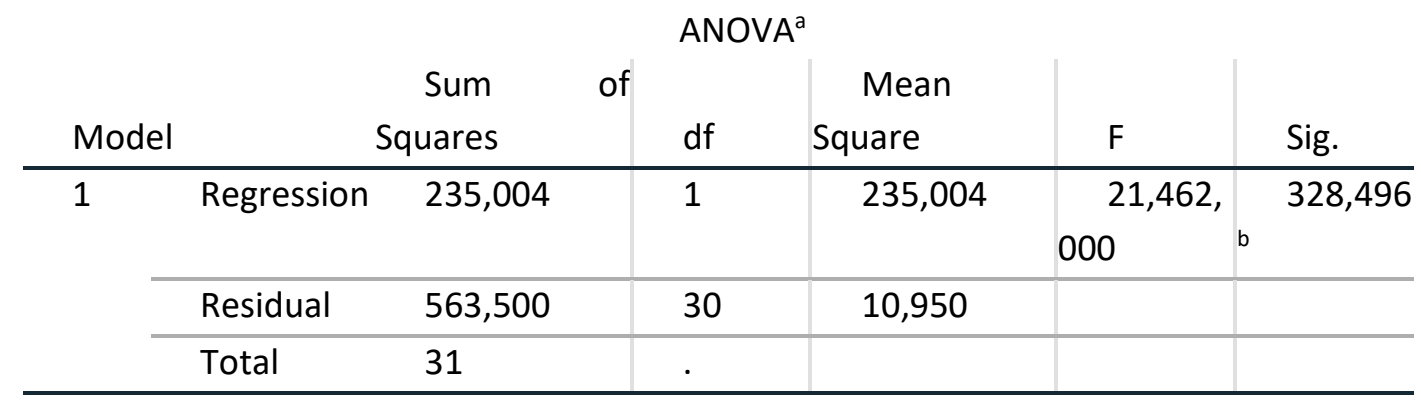

aDependent Variable: Participation Rate of UNEJ Student Support to NonGovernmental Organizations

b. Predictors: (Constant), Financial Reporting Accountability

Source: SPPS 2021 Data, processed

Table 6. Model Summary

\begin{tabular}{|c|c|c|c|c|}
\hline \multicolumn{2}{|c|}{ Mod } & \multirow{2}{*}{\multicolumn{2}{|c|}{$\begin{array}{l}\text { Adjusted } \\
\text { R Square Square }\end{array}$}} & R Std. Error of \\
\hline el & $\mathrm{R}$ & & & the Estimate \\
\hline 1 & $.646^{a}$ & $\begin{array}{l}.417 \\
.398\end{array}$ & 3.309 & $a$ \\
\hline
\end{tabular}

. Predictors: (Constant), Financial Reporting Accountability

Source: SPPS 2021 data, processed

From table 5 it can be seen that the regression equation is as follows:

$$
\begin{aligned}
& Y=a+b X \\
& Y=17.580+0.449 X
\end{aligned}
$$

So from table 5 . and the previous regression equation it can be concluded asfollowing:

1. The constant of 17,580 means that the consistent value of the Participation Rate variable for UNEJ Student Support to Non-Governmental Organizations ( $Y$ ) is 17,580 
2. The regression coefficient of 0.449 states that every $1 \%$ addition of the value of the Financial Reporting Accountability variable (X) causes an addition of 0.449 to the Level variable. UNEJ Student Support Participation to Non-Governmental Organizations ( $Y$ )

3. Based on the significance value in table 5. obtained a significance value of $0.000<0.05$, it can be concluded that the Financial Reporting Accountability variable (X) has a positive effect on the Participation Level of UNEJ Student Support to Non-Governmental Organizations $(Y)$

4. By looking at ha the significance value of $0.00<0.05$, then there is an influence between the two variables

5. . The value of the determinant coefficient (KD) is 0.417 which indicates that the Participation Level of UNEJ Student Support to Non-Governmental Organizations $(Y)$ is influenced by Financial Reporting Accountability (X) of $41.7 \%$, while $58.3 \%$ was influenced by other factors.

\section{Discussion}

Based on the results of the study, it is known that the significance value of the results of a simple linear regression test with SPSS software is $0.00<0.05$ which explains that there is an influence of financial reporting accountability on the level of participation of UNEJ students to governmental organizations, especially ICW as a focus. this research. In addition, with an R square value of 0.417 , it provides information that the existence of financial reporting accountability is strong enough to affect the participation rate of UNEJ student support for Non-Governmental Organization, which is $41.7 \%$, while the remaining $58.3 \%$ is influenced by other factors. With the findings of this study, it is also in line with Ulfah's statement (2018) which says that in the current era demands for accountability for financial reporting of public sector organizations are increasingly being demanded by the public. Even further, these demands in addition to leading to financial accountability but also targeting managerial accountability, legal accountability, and value for money accountability (Yuesti et.al, 2020). With this accountability, it also reinforces the goals and characteristics of the public sector itself, which is not profit, but rather has an orientation to public satisfaction. As in the public sector of Non-Governmental Organizations, the importance of financial reporting is a form of meeting the public interest and gaining sympathy for support in addition to being responsible for members of Non-Governmental Organizations and creditors (Haryono, 2019). So in other words the need for an open form of accountability for the operations of public sector organizations including Non-Governmental Organizations is a form of obligation that must be fulfilled without exception.

This does not exclude students who are part of the public. Coupled with the characteristics of Non-Governmental Organization which are linear with students namely as a forum to empower the community in realizing a bureaucratic, legal, social, political and economic system that is socially just and free from corruption, the need for a form of financial reporting 
accountability is also needed by students to assess the extent to which the performance of NonGovernmental Organization ICWThis is in accordance with the purpose of financial reporting by Non-Governmental Organizations related to the use of financial statement information by external parties as an effort to assess the sustainability of the Non-Governmental Organization, as well as assessing liquidity, financial flexibility, ability to cover obligations, and external (Martani , 2020). In other words, the more Non-Governmental Organizations ICW reflects reliability and accuracy of financial information, the more positive it is for the public. Meanwhile, especially for students, the accountable financial reporting of Non-Governmental Organizations can provide an appropriate assessment of ICW so that all operational activities so far can truly be accounted for as they should be.

The value of financial reporting accountability at Non-Governmental Organizations is reflected in ICW's financial reports which are never absent to be displayed openly to the public with very easy access. In addition, the quality of ICW's financial reports is also reflected in the existence of audits conducted by public accounting firms that provide unqualified opinions on an ongoing basis. This reflects the quality of ICW's financial reporting, which is very convincing both in material terms and adheres to the principle of using ISAK 35 which has been in force in Indonesia since January 1, 2020. This is evidenced by the example of the comparison of ICW's financial statements with the ISAK 35 format:

A2 nocosus

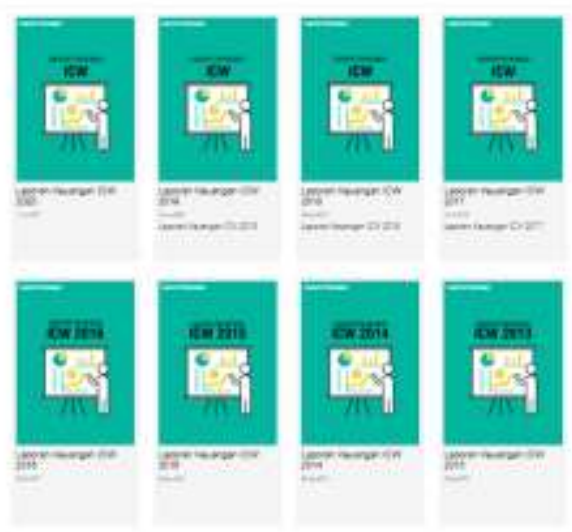

nims - wis s

Figure 1. Ease of Access ICW Financial Report 


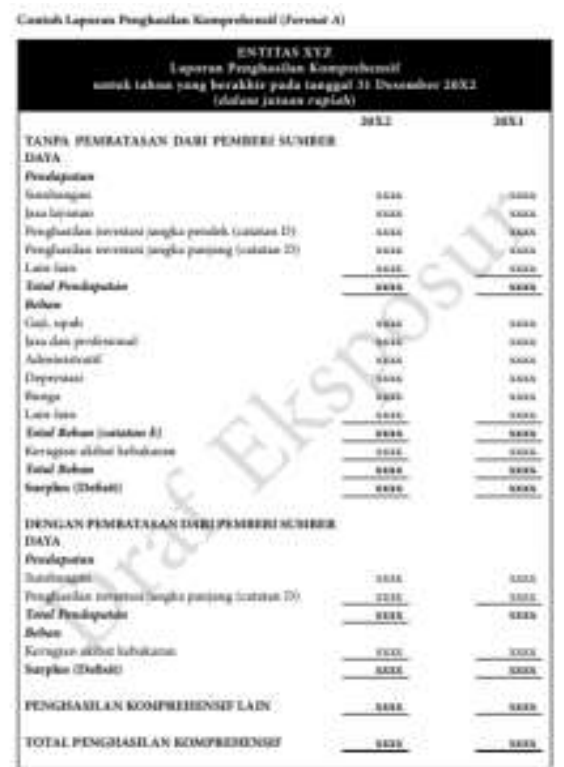

Figure 2. Income Report Format according to ISAK 35

Source: http://iaiglobal.or.id/v03/files/file berita/DE\%20ISAK\%2035.pdf

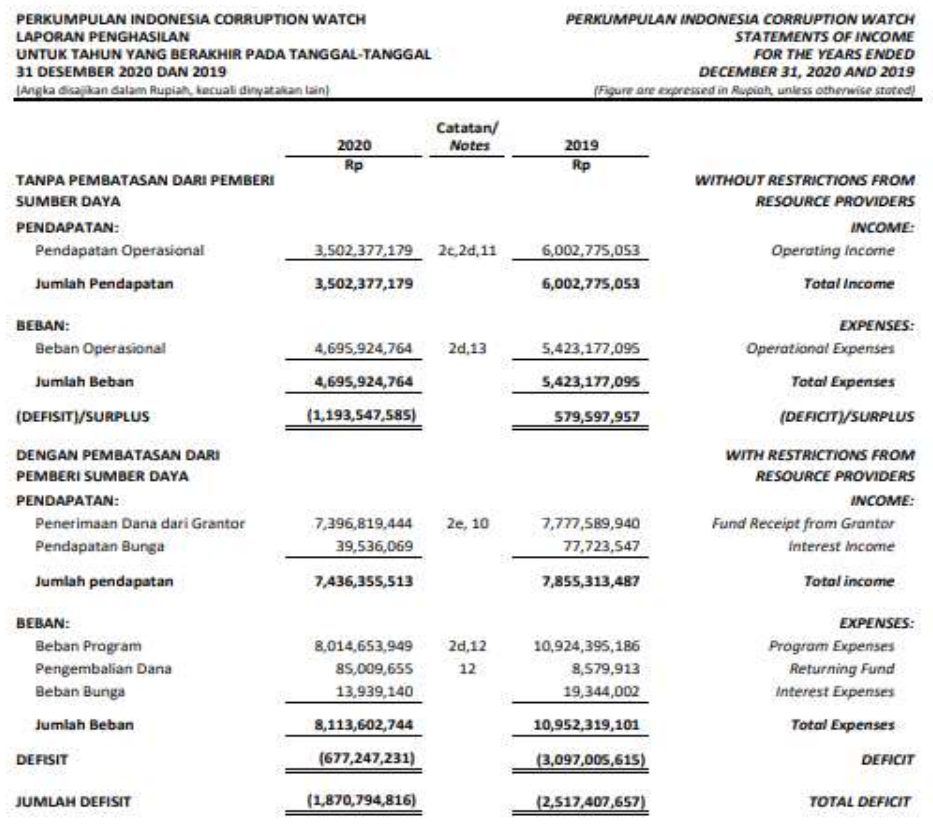

Figure 3. Non-Governmental Organization 2020

As seen in Figure 2. that the use of ICW income report format in 2020 uses the type A format from the ISAK 35 pilot as shown in Figure 1. In addition, it is also clear how the use of the term "comprehensive income" is used to indicate the amount of surplus (deficit) and other comprehensive income which of course is in accordance with the reflection of ISAK 35 . In addition, other types of financial statements besides comprehensive income financial statements 
are also presented. According to ISAK 35 rules, which reflect a fairly high value of accountability, the Non-Governmental Organization (NGO) ICW has shown it as a reliable form of accountability to the public.

\section{Conclusion}

From the results of the research that has been presented, it can be concluded that: The significance value is $0.000<0.005$, it can be concluded that the Financial Reporting Accountability variable $(X)$ has a positive effect on the Participation Rate of UNEJ Student Support to NonGovernmental Organizations (Y) The value of the determinant coefficient (KD) of 0.417 which indicates that the Participation Rate of UNEJ Student Support to Non-Governmental Organizations $(\mathrm{Y})$ is influenced by Financial Reporting Accountability $(\mathrm{X})$ of $41.7 \%$, while $58.3 \%$ is influenced by other factors. The importance accountability by Non-Governmental Organizations is a form of responsibility to the public (one of them is students), as well as being able to attract support participation to the organization

\section{References}

Andarsari, P. R. (2016). Laporan Keuangan Organisasi Nirlaba (Lembaga Masjid). EKONIKA Jurnal Ekonomi Universitas Kadiri, 1(2).

Aziiz, M. N., \& Prastiti, S. D. (2019). Faktor-Faktor Yang Mempengaruhi Akuntabilitas Dana Desa. Jurnal Akuntansi Aktual, 334.

DSAK IAI. (2018). DE ISAK 35 Penyajikan Laporan Keuangan Entitas Berorientasi Non Laba. DSAK IAI: Jakarta.

Ferdinand, A. (2014). Metode Penelitian Manajemen. Semarang: BP Universitas Diponegoro.

Ghozali, I. (2011). Aplikasi Analisis Multivariate Dengan Program IBM SPSS 19, Semarang . Badan Penerbit Universitas Diponogoro.

Haryono, F. (2019). EVALUASI PENERAPAN PSAK NO. 45 TENTANG PELAPORAN KEUANGAN ENTITAS NIRLABA PADA JEMAAT GMIM SION TELING SENTRUM MANADO. Jurnal EMBA: Jurnal Riset Ekonomi, Manajemen, Bisnis Dan Akuntansi.

Imaniar, F. Q., \& Kurnia, K. (2016). Faktor-Faktor Yang Mempengaruhi Ketepatan Waktu Pelaporan Keuangan Perusahaan. Jurnal Ilmu Dan Riset Akuntansi (JIRA), 5(6).

Martini, D. (2020) PSAK 45 Organisasi Nirlaba. Departemen Akuntansi FEB UI: Jakarta

Notoatmodjo, S. (2012). Metodologi Penelitian Kesehatan. Alfabeta: Bandung

Nuzul, A. A. (2019). Peran Lembaga Swadaya Masyarakat (LSM) Hysteria Dalam Pengembangan Ekonomi Lokal Masyarakat Di Kampung Bustaman Kelurahan Purwodinatan Kota Semarang (Doctoral Dissertation, UIN Walisongo). 
Priharta, A. (2017). Pengaruh Corporate Governance Terhadap Integritas Laporan Keuangan. JABE (Journal Of Applied Business And Economic), 3(4), 234-250.

Priyatno, D. (2009). 5 Jam Belajar Olah Data Dengan SPSS. Yogyakarta: Elex Media Komputindo.

Ronasifah, F., Ati, N. U., \& Hayat, H. (2019). PERAN LEMBAGA SWADAYA MASYARAKAT (LSM) CAKRAWALA KEADILAN DALAM PEMBERDAYAAN LINGKUNGAN (Studi Tentang Gerakan Peduli Sampah Di Desa Paciran Kecamatan Paciran Kabupaten Lamongan). Respon Publik, 13(3), 53-61.

Smadi, A. A., \& Abu-Afouna, N. H. (2012). On Least Squares Estimation In A Simple Linear Regression Model With Periodically Correlated Errors: A Cautionary Note. Austrian Journal Of Statistics, 41(3), 211-226.

Sugiyono. (2008). Metode Penelitian Pendidikan:(Pendekatan Kuantitatif, Kualitatif Dan R \& D). Alfabeta

Sugiyono. (2011). Metode Penelitian Kuantitatif, Kualitatif Dan R\&D. Bandung: PT Alfabet.

Sugiyono. (2016). Metode Penelitian Kuantitatif Dan R\&D. Bandung: PT Alfabet.

Ulfah, I. F. (2018). AKUNTABILITAS DAN TRANSPARANSI PENGELOLAAN KEUANGAN PADA PANTI ASUHAN AL MAA'UUN. In Seminar Nasional Dan Call For Paper III Fakultas Ekonomi (Pp. 216-225).

Yuesti, A., Dewi, N. P. S., Dan Pramesti, I. G. A. A. (2020). Akuntansi Sektor Publik. CV Noah Alethia: Bali. 